\title{
Bioetika i autonomija osobe s invaliditetom po načelu supsidijarnosti
}

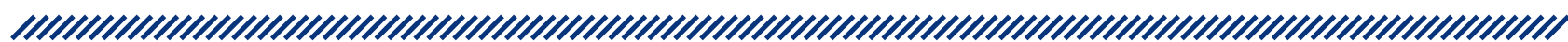

\author{
1 Mario Bebek \\ 1 Marija Brdarević \\ 1 Zdravstveno veleučilište, Zagreb
}

\section{Sažetak}

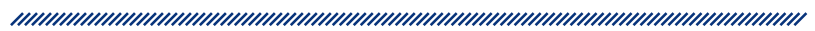

Osobe s invaliditetom sposobne su za zapošljavanje, ali ih poslodavci ne zapošljavaju dovoljno. Te činjenice znatno utječu na njihovu kvalitetu života, kao i na samopercepciju osobe. Načelo supsidijarnosti u sklopu primijenjene bioetike može izazvati pomake na društvenoj razini i pomoći u rješavanju tog problema. Demografski su čimbenici poražavajući za kvalitetu života i rada osoba s invaliditetom. Negativni učinci krize morala u društvu upućuju na nesklad između materijalnog i duhovnog, moralnog i prevladavajućeg vrijednosnog sustava društva i pogađaju najranjivije skupine, a to su osobe s invaliditetom, i to u njihovu školovanju, radu i osobnom životu. Zajednička sinergija bioetike kao sveobuhvatnog teorijskog korektiva i učinkovite prakse jest putovanje prema autonomiji osobe s invaliditetom. Javnost mora pomoći i dopustiti osobama s invaliditetom da budu percipirane kao ravnopravni članovi društva. Pozitivan ishod nije ostvariv bez primjene načela supsidijarnosti.
Ključne riječi: bioetika, kompetencije osobe s invaliditetom, načelo supsidijarnosti, timski rad i multidisciplinarni pristup

Datum primitka: 15.05.2018.

Datum prihvaćanja: 10.10.2018.

DOI: $10.24141 / 1 / 5 / 1 / 13$

Adresa za dopisivanje:

Marija Brdarević

Zdravstveno veleučilište, Mlinarska 38, Zagreb

tel.: +385914595712

e-pošta: marija.brdarevic@zvu.hr 


\section{Uvod}

Osobe s invaliditetom sastavni su dio društva u kojem živimo te obuhvaćaju sve osobe koje imaju dugotrajna tjelesna, mentalna, intelektualna ili osjetilna oštećenja. U međudjelovanju s ljudima različite prepreke mogu sprječavati njihovo puno i učinkovito sudjelovanje u društvu na ravnopravnoj osnovi s drugima. Društvo je ključna komponenta jer svojom neprilagođenošću stvara određene prepreke i diskriminira, ali ih isto tako može ukloniti kroz tehničke prilagodbe prostora te osiguranje pomagala i drugih oblika podrške. Cilj je rada osvijestiti i razmotriti put interdisciplinarnog pristupa u edukaciji i radu osobe s invaliditetom kroz znanje iz primijenjene bioetike s posebnim naglaskom moralnog načela supsidijarnosti. U radu slijedi kratak pregled značaja i razvoja bioetike u svijetu i Republici Hrvatskoj, kao i isticanje njezine važnosti za rad osobe s invaliditetom. U nastavku rada bit će istaknuto značenje supsidijarnosti, sadržaj i opseg pojma kroz konkretne primjere povezane s radom osoba s invaliditetom te kroz kvalitativno istraživanje i osvrt na probleme sa zapošljavanjem. Središnji dio rada istaknut će etičke probleme u primjeni načela supsidijarnosti, a glavna misao istaknut će opravdanost znanja koja u konkretnim životnim situacijama imaju i pozitivne i negativne strane. Zaključna misao ima cilj prevladati raskorak između očekivanog i stvarnog načina života, kao i potaknuti potencijalne poslodavce da se ne boje zaposliti osobe s invaliditetom. Sažeta poruka rada bila bi primjena holističkog pristupa prema svakom čovjeku, a metode bolja komunikacija, aktivno slušanje i kontinuirano učenje empatije i timskog rada. Jasno mjerljivim rezultatima, kritičkim mišljenjem $\mathrm{i}$ indikatorima kvalitete bit će opisana društvena svijest u odnosu na primjenu integrativne bioetike danas. Preporuka je prakticiranje načela supsidijarnosti na osobnoj razini te vizija novog pogleda u praksi iz perspektive osobe s invaliditetom.

\section{Bioetika - kratka povijest i razvitak}

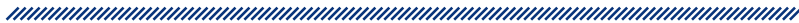

Bioetika kao društveni pokret i kao nova znanstvena disciplina naglo se razvila sredinom 20. stoljeća jer se znatno povećao utjecaj tehnoloških dostignuća i inovacija u medicini, što je neizbježno dovelo i do promjena u odnosu zdravstvenih radnika i bolesnika. Pojavili su se brojni pravni i etički problemi u medicini, za čije je rješavanje nužan multidisciplinaran pristup. Tradicionalna etika nije mogla pratiti znanstveno-tehnološki napredak. Medicina i biomedicinska znanost razvijale su se oduvijek usporedo s ostalim prirodnim znanostima. Ovi novi i često prijeporni odnosi u obavljanju medicinske djelatnosti i skrbi o bolesniku mogu se kvalitetno riješiti samo zajedničkim radom stručnjaka iz područja medicine, prava i bioetike. Cjelokupno čovječanstvo suočilo se s novim etičkim pitanjima. Uzrokom nastanka bioetike može se smatrati ubrzani napredak znanosti i tehnike (prvenstveno u području biomedicinskih znanosti i kliničke medicine), odnosno novostečena moć u stvaranju, manipuliranju, održavanju i okončavanju života. U tom smislu mogu se spomenuti nove reproduktivne tehnike, novi proboji u području genetike, nove spoznaje i metode u dijagnosticiranju i liječenju dotad nepoznatih i neizlječivih bolesti, a posebno novi načini produžavanja i održavanja života kao što su strojevi za dijalizu, „umjetna pluća”, „umjetno srce”, transplantacije organa itd. Sve intenzivnijima bivali su zahtjevi građana za većim nadzorom i utjecajem u sustavu liječenja i zdravstvene skrbi, a sve češće rezultirali su i organiziranom akcijom. ${ }^{1}$ Dakle, strojevi su zamijenili mnoge ljudske ruke, ali i zavladali čovjekom sve do danas. Mnoga otkrića otvarala su vrata raznim zloupotrebama. ${ }^{2}$ lako je znanstveno-tehnički napredak u velikoj mjeri pridonio kvaliteti života, osobito onih ljudi kojima su nova sredstva bila potrebna, a i sve dostupnija, počele su se pojavljivati učestale i, što je još važnije, sustavne moralne dvojbe koje je taj napredak izazvao. Nevjerojatno uvećana moć znanstvenika i liječnika ubrzo je rezultirala sviješću o stvarnim ili mogućim posljedicama nove tehnološko-znanstvene moći, pa i njezinim radikalnim propitivanjem, pri čemu je postalo očigledno da tradicionalni etički aparat ne može ponuditi odgovore na nova pitanja. Stoga se, nedugo potom, spomenutim civilnim inicijativama priključila teorijska refleksija, što znači da su konkretna pitanja iz prakse dala poticaj teoriji, a teorija je zauzvrat usustavila pitanja koja su se pojavljivala 
te etablirala bioetički pristup. U tom ozračju bit će i ovaj rad. Konkretna situacija, u ovom slučaju praksa osobe s invaliditetom, pokazat će potrebu za osloncem u teoriji morala, tj. načelu supsidijarnosti. Nastanak bioetike, $\mathrm{u}$ pregledima njezine povijesti, često se povezuje s osnivanjem prvog etičkog komiteta 1962. godine u Seattleu (SAD), u tamošnjem centru za hemodijalizu. ${ }^{2}$ Odmah nakon što je stavljen u funkciju stroj za dijalizu bubrega, pojavio se nerazmjer između tehničkih mogućnosti centra i broja potrebitih bolesnika. Pojavio se također uvid u to da odluku o tome kojim će pacijentima biti omogućena dijaliza ne mogu donositi samo djelatnici te medicinske ustanove, jer to nije puka tehnička odluka o kojoj se može odlučiti na temelju medicinske stručnosti, nego je riječ o etičkoj odluci koja zapravo presuđuje o kvaliteti života pacijenata ili čak o tome tko će živjeti, a tko umrijeti. Stoga je osnovan etički komitet, koji je zbog težine odluka o kojima je vijećao i zbog svojih ovlasti prozvan „Božjim komitetom” te izazvao burne reakcije u javnosti. Naziv „bioetika” i prvi teorijski koncept bioetike nastao je tek početkom sedamdesetih godina, zahvaljujući američkom znanstveniku Vanu Rensselaeru Potteru koji je 1970. u dva svoja članka te godinu dana nakon toga u knjizi Bioetika: most prema budućnosti skovao termin „bioetika”, te izložio vlastitu koncepciju bioetike. Potterova je namjera bila da u svrhu rješavanja gorućih problema čovječanstva, a uz pomoć onoga što je nazvao bioetikom, pridonese premošćivanju jaza između prirodnih i društvenih znanosti. ${ }^{2}$ Povijesna krilatica „znanje je vrlina i moć” u novom kontekstu priznaje se samo ako se primjenjuje u svjetlu moralnih normi. Njegov je motiv pritom bila, s jedne strane, nezainteresiranost etike i drugih društvenih i humanističkih znanosti za rastuće dvojbe u medicinskoj praksi i biomedicinskim istraživanjima, kao i za ekološka pitanja o kojima u to vrijeme još nije bilo tako široko diskutirano kao danas. $S$ druge strane, njegove je bioetičke ideje motivirala nezainteresiranost liječnika i prirodnih znanstvenika za promišljanje i konceptualiziranje rastućih problema s kojima se svakodnevno susreću u praksi. ${ }^{3}$ „Potterov slučaj” pokazuje da, iako je bioetika, povijesno gledajući, proizišla iz problemskog polja medicinske etike, u svojim osnovama nosi prekoračivanje medicinsko-etičkog okvira. Zaoštrene moralne dvojbe koje je proizveo znanstveno-tehnički napredak u području medicine jednostavno su tražile širi orijentacijski horizont. Stoga je bioetika relativno brzo prošla kroz razvojnu preobrazbu kojom je svoje predmetno područje proširila preko granica medicine i biomedicinskih znanosti do globalno-ekoloških problema. Suvremena bioetička rasprava tako obuhvaća ne samo pitanja medicinske skrbi i biomedicinskih istraživanja nego i probleme koji se tiču neljudskih živih bića i prirode u cjelini, kao i problematiku uloge i smisla znanosti uopće, sve do fundamentalnih pitanja zapadne civilizacije i opstanka čovječanstva. ${ }^{2}$ Pomak se zbiva i na metodološkom planu, gdje je bioetika nadrasla neposrednu moralnu refleksiju, svojstvenu prvome razdoblju u razvoju bioetike, te se uzdigla do razine etičke refleksije. ${ }^{4}$ Javlja se potreba integracije znanosti i pojava novog puta u etici, a to je pluriperspektivizam koji znači pluralizam istine, a sastoji se u mnogostrukosti njezinih aspekata i perspektiva u kojima se sagledavaju. ${ }^{5}$ Zanimljivo su otkriće europski korijeni bioetike, i to kada se već čvrsto prihvatila teza da je otac termina „bioetika” V. R. Potter. ${ }^{2}$ lako otkrivena punih sedamdeset godina kasnije, na predavanju Sveučilišta Humboldt snažno je odjeknula istina da je već 1927. godine njemački pastor i etičar Fritz Jahr u svojem članku: „, Bioetika. Osvrt na etički odnos čovjeka prema životinjama i biljkama" prvi tvorac neologizma „bioetika” koji postaje temelj nove znanstvene paradigme. ${ }^{2}$ Fritz Jahr moralnim promišljanjem formulirao je bioetički imperativ koji je nastavio Kantov kategorički imperativ kao vodič za moralne dužnosti i odgovornosti u svim znanostima koje se bave životom, i to svim oblicima života. ${ }^{3}$ Tako je suptilno Fritz Jahr postao europski Potter sa širokom bioetičkom platformom među europskim i svjetskim znanstvenicima.

U ovako skraćenom prikazu primjetno je da je bioetika tijekom svoje kratke povijesti doživljavala velike strukturne promjene, kako s obzirom na predmetno područje tako i s obzirom na metodologiju. Razvojne mijene tog novog i dinamičnog područja, iako s nekoliko desetljeća zakašnjenja, reflektirale su se i u Hrvatskoj, pri čemu se ne može previdjeti lokalne posebnosti, kao ni činjenicu da je bioetika u Hrvatskoj u posljednjih nekoliko godina učinila znatne iskorake koji su vidljivi i na svjetskoj razini.

\subsection{Bioetika u Republici Hrvatskoj}

Bioetika je u samo desetak godina izrasla u snažno i produktivno područje teorijskog i praktičkog angažmana te su pitanja iz problemskog područja bioetike postala predmetom interesa šire javnosti Hrvatske. U dvobroju časopisa Društvena istraživanja (1996.) objavljena je tema pod naslovom „Nova medicinska etika”. Akademik Ivan Supek napisao je: „Znanstvenici imaju najveću odgovornost da očuvaju i ojačaju etička načela u svojim istraživanjima i ustanovama." ${ }^{7}$ Urednik teme u uvodniku čitatelje upućuje da je „nova medicinska etika, koja je zakoračila u četvrto desetljeće svog života 
osvojivši pritom prethodno gotovo sav razvijeni svijet, potrebna i Hrvatskoj"s. Reprezentativan izbor članaka stranih i domaćih autora o ovoj „novoj i izrazito propulzivnoj znanstvenoj disciplini", objavljen na stranicama Društvenih istraživanja, imao je - kako se danas vidi dalekosežan učinak, jer je bioetiku na najbolji mogući način predstavio domaćoj javnosti i time pobudio interes za bioetiku među znanstvenicima koji dotad s njome nisu bili upoznati.

Urednik Ivan Šegota već je i ranije učinio važne korake za uvođenje bioetike u znanstveno-akademsku zajednicu. Na Katedri društvenih znanosti Medicinskog fakulteta Sveučilišta u Rijeci još su 1992. godine u nastavu uključeni sadržaji i predmeti koji su promovirali nove teme i pristupe u području medicinske etike, zahvaljujući prije svega Šegotinim kontaktima s uglednim svjetskim bioetičarima, uključujući i „oca bioetike” Vana Rensselaera Pottera, s kojim je osobno komunicirao. Treba istaknuti da je razvijen i „riječki model bioetičke edukacije", koji je bio inovativan ne samo u okvirima hrvatskog visokog školstva nego i u svjetskim razmjerima, a uskoro se počelo i s izdavanjem bioetičkih publikacija koje su do danas ostale relevantnim bioetičkim štivom. Stoga se krug znanstvenika i nastavnika koncentriran na ovoj katedri s pravom može smatrati predvodnicima razvoja bioetike u Hrvatskoj. ${ }^{1}$

Bioetička se edukacija, pod imenom medicinske etike i bioetike ili u okviru drugih predmeta, polako širila i na druga hrvatska visoka učilišta, i to kako medicinska, tako i društveno-humanistička, prirodoslovna i tehnička, čemu su se priključivali i drugi vidovi bioetičkih aktivnosti. Glavno „gnijezdo” bioetike danas je u Hrvatskoj Fakultet filozofije i religijskih znanosti Sveučilišta u Zagrebu, ali i svi drugi fakulteti imaju svoje aktivne profesore. Interdisciplinarne rasprave i znanstveni skupovi dali su presudan poticaj daljnjem i ubrzanom razvoju bioetike u Hrvatskoj, jer su omogućili plodotvoran dijalog i umrežavanje znanstvenika zainteresiranih za bioetička pitanja. No u ovom je slučaju to imalo i jednu dodatnu dimenziju. Početni impuls s Medicinskog fakulteta Sveučilišta u Rijeci dodatni je zamah dobio 1998. godine održavanjem simpozija „Izazovi bioetike” u okviru znanstveno-kulturne manifestacije Dani Frane Petrića, koju Hrvatsko filozofsko društvo od 1992. organizira u Cresu. Izbor radova s tog skupa objavljen je najprije u časopisu Hrvatskoga filozofskog društva Filozofska istraživanja, a potom i u posebnoj knjizi. ${ }^{9}$ Tri godine kasnije, 2001. - također u okviru Dana Frane Petrića, ali ovog puta u Malom Lošinju - održan je međunarodni simpozij „Bioetika i znanost u novoj epohi”, a izbor radova ponovno je objavljen u časopisu Filozofska istraživanja. ${ }^{10}$ Entuzijazam i optimizam kojima je skup bio prožet uvelike su utjecali na formiranje hrvatske „bioetičke zajednice” i uključivanje hrvatskih bioetičara u međunarodnu bioetičku raspravu. Tome je pridonijela i pozdravna poruka koju je „otac bioetike” Van Rensselaer Potter u audiovizualnom obliku, tek nekoliko mjeseci prije smrti, uputio tom bioetičkom simpoziju. Kako ističe Ante Čović, ta je poruka skupu „pribavila posebnu povijesnu, legitimacijsku i simboličku važnost”. U poruci je Potter, među ostalim, izrazio nadu da će taj simpozij „dati novi poticaj bioetici u Hrvatskoj, kao i u susjednim zemljama". ${ }^{11}$ Lošinjski dani bioetike u sedamnaest godina održavanja prerasli su u temeljnu instituciju bioetičkog života i bioetičke rasprave u ovom dijelu Europe. Središnje mjesto u okviru Lošinjskih dana bioetike zauzima međunarodni simpozij o stalnoj temi „Integrativna bioetika i nova epoha". Osnovna je zamisao tog simpozija uspostavljanje interdisciplinarnog i pluriperspektivnog dijaloga o temeljnim problemima suvremene civilizacije, koji polazi od ideje da je bioetika inovativno duhovno područje u kojem se uspostavljaju različite teorijske i praktične interakcije (interdisciplinarni, internacionalni, interkulturalni, interkonfesionalni itd. odnosi) i sabire ukupnost perspektiva ljudskog opstanka (pluriperspektivizam) radi postavljanja orijentira i postizanja orijentacijskog znanja u situaciji prelamanja epoha svjetske povijesti. Temeljna je osobina tih skupova otvorenost dijalogu i poticanje interakcije različitih perspektiva i pristupa u diskusiji o tematiziranim pitanjima. Bioetika se javlja kao iznimno važna manifestacija ljudske prirode u novoj situaciji te upućuje na promjenu odnosa spram čovjeka i prirode. U bioetičkom senzibilitetu, prema autorici Ivani Zagorac, mogućnost ljudske spoznaje u racionalističkoj paradigmi pouzdaje se u osjetilnu, ali i osjećajnu sposobnost čovjeka. U bioetičkom diskursu pojam senzibiliteta opisuje naglašenu osjetljivost prema okolini, implicira moralno reflektirano odnošenje prema ljudskoj egzistenciji i drugim živim bićima te sadrži prosvjetiteljsku naklonost prema slabijima i nezaštićenima, što se prepoznaje u realizaciji principa solidarnosti i supsidijarnosti. ${ }^{12}$ Razvojni uspon bioetike u Hrvatskoj zbog svoje integrativnosti i pluriperspektivnosti postaje i znak i akter prijelomnog vremena u povijesti svijeta. Znanstvena potvrda tog društvenog pokreta rezultirala je 2014., na prijedlog Nacionalnog vijeća za znanost, Znanstvenim centrom izvrsnosti za integrativnu bioetiku. Kroz definiciju bioetike „Ljubav prema životu" tu paradigmu znanja u budućnosti tek treba istražiti. Autori ovog teksta kao aktivni sudionici tog važnog skupa žele potaknuti studente na rad i istra- 
živanja u bioetici. Upravo načelo supsidijarnosti bit će glavna tema ovog rada koja otvara nove horizonte na liniji „starih” pojmova poštovanja, ljubavi i suosjećanja. Bioetički senzibilitet tako se javlja kao bitna sastavnica humanosti uz visoku razinu respekta, ponovno pronalazeći svoje mjesto pokraj „hladne” racionalnosti. Važno je postaviti moralne granice. Cijeli razvoj bioetičke znanstveno-stručne rasprave $\mathrm{i}$ bioetički senzibilitet reflektira se i na razini institucije, jer, kao ni u svijetu, tako ni kod nas bioetičke institucije i institucionalni mehanizmi nisu nastajali iznenada, nego su rezultat određenih potreba koje su osviještene u javnosti, odnosno „napretka u svijesti” o važnosti svih problema koji ne mogu biti ni artikulirani ni riješeni bez primjerene institucionalizacije. ${ }^{2}$ Stvaranje interdisciplinarne mreže bioetičara, koja se profilirala putem skupova, publikacija i edukacijskih programa, zatim spajanje zasebno vođenih rasprava o biomedicinskim i ekološkim pitanjima, a konačno i društveni utjecaj, vidljiv preko razvijanja bioetičkog senzibiliteta i institucionalizacije - stvorili su povoljnu atmosferu koja je omogućila nastanak originalnih ideja i inovativnih koncepata koji su latentno bili prisutni gotovo od samih početaka bioetike u Hrvatskoj. Ono što je danas veliki napredak u moralnom aspektu i daje nadu osobama s invaliditetom jest spoznaja da su na svim razinama društva zaživjela etička povjerenstva, koja su smjernica i putokaz za sve odluke povezane s čovjekom kao osobom i njegovim ljudskim pravima na moralnim temeljima i moralnim principima. $U$ toj nadi ovaj mali rad želi potaknuti da princip supsidijarnosti zaživi na osobnoj, ali još više na institucionalnoj razini. $U$ daljnjoj se razradi stoga rad bavi tim načelom u teorijskom i praktičnom smislu.

\section{Supsidijarnost kao moralno načelo}

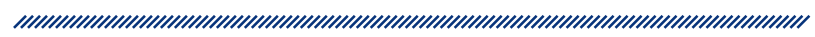

Supsidijarnost je načelo po kojem se odluke donose i problemi rješavaju u obliku kategorija i na razinama na kojima nastaju. ${ }^{13}$ Svi poslovni problemi rješavaju se u okviru funkcijske, logičke, kronološke te lokacijske kategorije. Moralno načelo supsidijarnosti zahtijeva da fokusiramo osjećaj interesa, ugode, koncentracije i snage u skladu s pravilno definiranom vizijom, misijom, ciljevima i zadacima nas samih. Potrebno je fokusirati emocije, uvjerenja, osjećaje i stavove tako da se osjećamo zadovoljni u trenucima usmjereni prema nekom željenom cilju. Osobe, organizacije i dijelovi organizacije koji imaju kontradiktorne želje, misli, ciljeve i osjećaje u poziciji su vozača koji istodobno pritišće papučicu gasa i kočnicu. Supsidijarnost također govori da je načelo prema kojemu odlučivanje o zajedničkim pitanjima mora biti preneseno na najniži mogući stupanj društvene organizacije, dok središnja vlast ima samo ulogu nadopune stručnog djelovanja i odlučivanja na mjesnoj razini. S povijesnog aspekta, sam pojam supsidijarnost dolazi od latinske riječi subsidium, iz rimskoga vojnog govora, a označavao je one vojnike koje su bili u „pričuvi, rezervi, pomoći” i koji su trebali pohrliti u pomoć ako bi oni na prvoj crti popustili. Tada se taj pojam počeo upotrebljavati u društvenoj teoriji u značenju da veća društvena zajednica mora priskočiti u pomoć manjoj zajednici ili pojedincu kada ovi zapadnu u poteškoće. Prema katoličkom društvenom nauku, supsidijarnost je opća norma naravnog prava koja utemeljuje svako uređenje ljudskog društva. ${ }^{13}$ To je načelo važan princip socijalne filozofije, a glasi da nije dopušteno oduzeti pojedincima ono što mogu obavljati vlastitim sposobnostima, poticajima i sredstvima. Drugim riječima, protiv pravednosti je da se aktivnosti koje mogu činiti manje skupine svojim silama i sredstvima prepuste većem društvu. Društvo je pravedno ako pomaže manjim skupinama i pojedincu, a nije pravedno ako ih zamjenjuje i apsorbira. ${ }^{14}$

U središtu solidarnosti i supsidijarnosti jest čovjek, njegovo dostojanstvo i njegova prava. ${ }^{13}$ Supsidijarnost vodi k ostvarenju općeg dobra, podsjećajući da su duhovna dobra i vrline važnije od materijalnih koje su namijenjene svima. Zato je načelo supsidijarnosti način života koji svakom čovjeku daje šansu da se ostvari u sposobnostima koje ima a da se ne osjeća manje vrijedan ako nešto ne može odraditi. U toj situaciji nije sam. Tu je i drugi čovjek uz njega. Takav način suživota nužan je za ostvarenje mira, sveopćeg razvoja pojedinca i ljudske zajednice. Svaki uspjeh nije samo uspjeh pojedinca, već i šire zajednice. Kroz jačanje vrline zajedništva, sinergijom, moguće je ostvariti mnoge ciljeve, ali i kvalitetu ljudskog suživota. ${ }^{15}$

Pojam supsidijarnosti kao moralni princip karakterističan je upravo za katolički socijalni nauk. Njegov je prvi tvorac apostol Pavao iz Tarza. Samo u dvadesetak godina binarnim sustavom širio se po Europi i zaživio velikom brzinom eksponencijalno, i to još u vrijeme progona kršćana. Socijalna osjetljivost i altruizam glavne su odlike tog principa i razlog zašto je taj nauk opstao 
do danas. Socijalna se etika prije svega bavi društvenim poretkom, a ne individualnim ponašanjem pojedinih ljudi u društvu. Područja su socijalne etike socijalne prirode i tiču se čovjekova suživota s drugim ljudima. Uz socijalnu etiku, i opća etika pogađa individualno ponašanje jednoga čovjeka prema drugom čovjeku. Etika ima veliku važnost, i to: izraditi, izreći, formulirati i utemeljiti norme za čovjekovo djelovanje. Zato djelovanje u okviru socijalnog i političkog područja spada pod etičke norme. Društveni se odnosi ubrajaju u svjesno i slobodno ljudsko oblikovanje. Socijalni život, osobito u svojim pojedinačnim odnosima, nije određen nepromjenjivim zakonima tako da čovjek ne bi mogao na njega utjecati svojom sviješću, odgovornošću, slobodom, usmjeravanjem i navikama. Kriterije za prosudbu takvih razvoja za čovjekovo dobro postavlja socijalna etika. U korijenu je svih zakona moral. Znači, birati i tražiti dobro, kao apsolutnu vrijednost, a izbjegavati štetu i zlo za pojedinca i za opće dobro. Definirano je kako nije dobro pojedincima oduzimati i predavati državi one poslove koje oni mogu obaviti na vlastitu odgovornost i vlastitom marljivošću te da je nepravedno i u visokom stupnju škodljivo za javni poredak te opasno davati većemu i višemu društvu one poslove koje mogu izvršavati manje i niže zajednice..$^{13}$ Svaka društvena ustanova mora po svojem značenju donositi pomoć uvodima društvenog tijela, a ne smiju ih nikada uništiti niti prisvojiti.

Princip supsidijarnosti u prvom je redu pravilo za utvrđivanje nadležnosti pri ostvarivanju zajedničkog dobra. Ono sto pojedinac može sam izvršiti svojom vlastitom snagom, to mu društvo ne smije oduzeti ili što može manja zajednica učiniti, to joj veće društvo ne smije uskratiti. Taj princip kaže da članovi neke zajednice imaju pravo na pomoć u svim poslovima i stvarima koji ne mogu izvršiti sami, a kao članovi društva moraju biti zaštićeni od premoći samoga društva. Taj princip tumači obranu slobodne inicijative u društvu i zauzima se za pravo manjih životnih krugova. ${ }^{16}$ Papa Pio XI. ovako izražava načelo supsidijarnosti:

„Kao što ne valja pojedincima oduzimati i predavati državi poslove koje oni mogu obavljati na vlastitu odgovornost i vlastitom marljivošću, tako je nepravedno i štetno za javni poredak i opasno davati većemu i višemu društvu poslove koje mogu obavljati manje i niže zajednice. Svaka društvena ustanova mora po svojemu pojmu i značenju pomagati (lat. subsidium - davanje pomoći) udovima društvenog tijela, a ne smije ih nikada ni uništiti ni posve prisvojiti."

\subsection{Načelo supsidijarnosti u radu osobe $s$ invaliditetom}

Supsidijarnost u radu osobe s invaliditetom ima veliki značaj. Prema načelu supsidijarnosti, za potrebe osoba s invaliditetom presudno je s viših instancija donošenja zakona provođenje zakona prebaciti na nižu instanciju u kojoj se ostvaruju i realiziraju zakoni. Zašto je to presudno? Ostvarivost zakona, kojima je svrha pomoći osobama s invaliditetom u njihovu samoostvarivanju unutar društvene zajednice, omogućava i njegovu primjenjivost u praksi, odnosno stvarnu pomoć konkretnoj osobi. Polazeći od osnovnog aksioma jednakosti svih osoba unutar društva zaključujemo da je načelo supsidijarnosti i njegova primjenjivost itekako potrebna i važna za konkretnu osobu s invaliditetom. ${ }^{17}$ Primarne ljudske potrebe svakog čovjeka kao vodu, hranu, zrak i san i njihovu ostvarivost nitko ne dovodi u pitanje. Sekundarne potrebe kao ljubav, prijateljstvo, poštovanje jednakost itd. u stvarnom životu za osobe s invaliditetom možemo dovesti u pitanje. Upravo je pitanje primjene zakona prema načelu supsidijarnosti važno u praksi za osobe $s$ invaliditetom i poštivanje njihovih sekundarnih potreba. Njihova su važnost ostvarivanje i potvrđivanje osobe unutar društvene zajednice kao ravnopravnih članova koji mogu skrbiti za sebe i biti samostalni, što znači uzdržavati se od vlastitog rada i biti sposobni osnovati obitelj. ${ }^{18}$

\subsection{Sastavnice koje izgrađuju načelo supsidijarnosti}

Osobe s invaliditetom su sposobne za zapošljavanje, ali ih poslodavci ne zapošljavaju dovoljno. Te činjenice znatno utječu na njihovu kvalitetu života kao i na samopercepciju osobe. Načelo supsidijarnosti u sklopu primijenjene bioetike može izazvati pomake na društvenoj razini i pomoći u rješavanju tog problema. Demografski su čimbenici poražavajući za kvalitetu života i rada osoba s invaliditetom. Negativni učinci krize morala u društvu upućuju na nesklad između materijalnog i duhovnog, moralnog i prevladavajućeg vrijednosnog sustava društva i pogađaju najranjivije skupine, a to su osobe s invaliditetom, i to u njihovu školovanju, radu i osobnom životu. ${ }^{19}$ Javnost mora pomoći i dopustiti osobama s invaliditetom da budu percipirane kao ravnopravni članovi društva. Pozitivni ishod nije ostvariv bez primjene načela supsidijarnosti.

1. Invalidnost - Kada govorimo o osobama s invaliditetom govorimo o osobama s fizičkim i mentalnim oštećenjima. Fizička oštećenja odnose se 
na fiziološke poremećaje ili anatomske gubitke koji mogu utjecati na brojne tjelesne funkcije. Mentalna oštećenja odnose se na mentalne ili psihološke poremećaje. Postoji mnogo tipova oštećenja pa se osobe $s$ invaliditetom razlikuju na temelju vrste i stupnja oštećenja. Kada ljudi čuju termin invaliditet ili osoba s invaliditetom, većina ima neku predrasudu i distancu prema njima. Svaki je čovjek vrijedan, isto kao i svačiji život te bi svakome trebalo dati istu šansu za sve u životu. Osobe s invaliditetom ne bi smjele biti manje slobodne osobe od drugih. ${ }^{17}$ Treba im se dopustiti maksimalna otvorenost i sloboda da se osjećaju potpuno prihvaćenima u društvu, neugroženima i korisnima za rad. Naravno, u onom radu koji ne mogu do kraja izvršiti sami trebalo bi im pomoći. Upotrijebiti načelo supsidijarnosti. Nisu sve osobe s invaliditetom iste i ne prihvaćaju sve osobe ravnomjerno pomoć. Svaka je osoba individua. Vrlo je važno znati je li invaliditet stečen pri rođenju ili tijekom života. Ako je invaliditet stečen tijekom života, onda je takvim osobama s invaliditetom mnogo teže prihvatiti taj invaliditet jer se teško naviknuti na njega i često kažu da žive u uvjerenju da mogu nešto napraviti sami, a ustvari više ne mogu. Teško im je priznati da taj neki rad koji su prije obavljali bez problema sada više ne mogu samostalno odraditi ili ne mogu odraditi uopće.

Primjerice, ako je slijepa osoba izgubila vid tijekom života, znatno joj je teže prilagoditi se situaciji nego nekome tko se rodio slijep. Valjan odnos obitelji i okoline prema invalidnosti važan je kod djece invalida. Važan je stav okoline prema osobi s invaliditetom, počevši od bolničke sredine pa do radne okoline i javnosti, jer je bitno da osoba $s$ invaliditetom ne izgubi društvenu ravnotežu. Okolina ne smije pokazivati ni nestrpljivost ni sažaljenje, naprotiv, mora pokazivati strpljenje te zdravo i potpuno razumijevanje. Tako osoba $s$ invaliditetom dobiva potpunu društvenu sigurnost. Važno je razvijati svijest o osobama s invaliditetom te shvatiti da su i to ljudi od krvi i mesa i da nisu manje vrijedni ako imaju neki hendikep te da ih zbog toga ne bi trebalo diskriminirati. Empatija se uči i podrazumijeva znanje i življenje. ${ }^{17}$ Aktivno slušanje i komunikacija isto se uči. To su vještine koje osiguravaju podršku i realiziraju kolegijalni odnos po principu supsidijarnosti i suživota. Takva je osoba spremna biti tu za „drugu” osobu, ali kad je ona zatreba.
2. Prihvaćanje - Kada je riječ o osobama s invaliditetom, susrećemo se $s$ raznim društvenim preprekama, bilo da je riječ o mentalnom invaliditetu bilo o tjelesnom invaliditetu. Međutim, tu su i česte predrasude ljudi prema osobama s invaliditetom. Zbog svojih ograničenja, invalidi se susreću s diskriminacijom te imaju znatno manje šanse za normalan život. Diskriminacija označava svako razlikovanje, isključivanje ili ograničavanje na osnovi invaliditeta koje ima svrhu ili učinak sprječavanja ili poništavanja priznavanja, uživanja ili korištenja svih ljudskih prava i temeljnih sloboda na političkom, ekonomskom, socijalnom, kulturnom, društvenom i svakom drugom području, na izjednačenoj osnovi s drugima. Uključuje sve oblike diskriminacije, uključujući i uskraćivanje razumne prilagodbe. Razumnom prilagodbom okoline i pružanjem podrške neovisnom življenju, kao i kompenzacijskim naknadama koje bi pokrivale rane troškove invaliditet bi se mogao svesti na najmanju mjeru. ${ }^{17}$ Time bi osoba koja je rođena s određenim oštećenjem ili koja je oštećenje stekla u bilo kojoj životnoj dobi zadržala svoje ljudsko dostojanstvo, mogućnost neovisnog života i uključenosti usprkos svojem ograničenju. Ali kako to i inače biva, osobe s invaliditetom prvo moraju prihvatiti same sebe kako bi ih i okolina mogla prihvatiti i uključiti u sve segmente društvene, poslovne ili bilo koje druge interakcije.

3. Princip solidarnosti - Društvo se sastoji od pojedinaca. Pojedinci su povezani time što stvaraju društvo i preuzimaju neke obveze $i$ odgovornosti. ${ }^{20}$ Ta međusobna povezanost pojedinca $i$ društva te obveze društva koje iz toga proizlaze izriču princip solidarnosti. Princip solidarnosti bitan je dio kršćanske socijalne teorije, a uveo ga je isusovac Heinrich Pesch koji je solidarnost izgradio u socijalno-filozofski sustav i prozvao ga solidarizmom. Princip načela solidarnosti znači postojeće stanje stvari, tj. činjenicu da su ljudi upućeni jedni na druge. Govori da su svi povezani sa sudbinom cjeline, kao što je i cjelina nerazdvojno povezana sa sudbinom pojedinaca. To je stanje zajedničke povezanosti. Iz tog se principa pojavljuju zahtjevi pa načelo solidarnosti postaje i princip dužnosti. ${ }^{20}$ To znači da se pojedinac mora zauzimati za dobro zajednice i prihvaćati njezinu sudbinu, kao i obratno. To je stanje zajedničke odgovornosti. 
4. Objektivnost - U poslovnom kontekstu objektivnost čini deduktivni niz koji se kreće od izbora radnog mjesta i dolazi do okoline preko udruživanja i razmjene. Poslovna objektivnost sastoji se od četiri koraka: izbor radnog mjesta, udruživanje, razmjena i okolina. ${ }^{19}$ Ova četiri koraka predstavljaju temelj kada govorimo o supsidijarnosti i zapošljavanju osoba s invaliditetom. Danas se ne zapošljava onoliko osoba s invaliditetom koliko bi trebalo. Razlozi su tome ograničenost $u$ određenim radnim aktivnostima, podcjenjivanje sposobnosti osoba s invaliditetom te strah od nepoznatog. Mnogi poslodavci odbijaju dugoročno zaposliti osobe $s$ invaliditetom zbog predrasuda o njihovim mogućnostima te bojazni da će se njihova manja produktivnost odraziti na smanjenje profita. Sigurno je da osobe s invaliditetom moraju mnogo pažljivije birati struku, obrazovanje te radno mjesto na kojem se žele zaposliti, ali ako zadovoljavaju osnovne uvjete koje radno mjesto zahtijeva i ako su u tom smislu apsolutno konkurentne, trebale bi dobiti šansu za samoostvarenje.

\section{Zapošljavanje osoba s invaliditetom po principima personalističke bioetike}

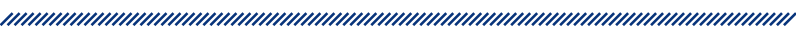

Elio Sgreccia, koji je u Rimu vodio prvu katedru za bioetiku 1983. i Centar za bioetiku, inzistira na principima „personalističke bioetike” koja uključuje temeljnu vrijednost života, slobodu i odgovornost te društvenost $\mathrm{i}$ supsidijarnost. ${ }^{21}$ Egzistencijalna i moralna kriza zahvatila je sva područja ljudskog djelovanja, a posao osoba $s$ invaliditetom zbog novih tehnoloških i znanstvenih dostignuća ozbiljno se mijenja. Prvenstveno se traži stručnost u formiranju tima, a zanemarene su ljudska i etička dimenzija. Dehumanizacija i gubitak autonomije udaljuju osobu od deklarativnog i stvarnog načina života. Samo povratak moralne svijesti pomaže svakom čovjeku da razlikuje dobro i zlo, a princip supsidijarnosti uvažava svaku osobu i vraća poljuljane moralne vrijednosti kao što su istina, pravednost i poštenje. Često se postavlja pitanje hoće li neka osoba naći posao kada dođe vrijeme za to. Tu se javljaju redoviti strah i gubitak samopouzdanja. Žalosno je da osobe s invaliditetom moraju znatno više dokazivati da nešto mogu napraviti i da su sposobne za neki rad od ljudi koji nemaju nikakav invaliditet. Jasno je da je invaliditet prepreka većini poslodavaca, ali ne mora biti presudan faktor. Možemo reći da je to krivi stav i krivo razmišljanje, to bi čak bio veliki plus za poslodavca i za poduzeće te je vrlo moguće da bi se mnoge druge tvrtke ugledale na tog poslodavca koji je zaposlio jednu ili više osoba s invaliditetom. Invaliditet je nevažan faktor ako je osoba sposobna za obavljanje onog dijela posla koji poslodavac očekuje od zaposlenika. ${ }^{17}$ Zašto se osobe $s$ invaliditetom često stavlja u kut? I oni su ljudi od krvi i mesa koji imaju pravo na normalan život i moraju živjeti od nečega jer se od zraka ne živi. Osobe s invaliditetom koje se trude u životu, koje su završile svoje školovanje i imaju silnu želju raditi možda su produktivniji i motiviraniji radnici od osoba koje nemaju takva ograničenja. Ne samo da su živi primjer drugim ljudima nego su i motivacija za rad drugim ljudima koji nemaju nikakav invaliditet. Jer sve se može kad se hoće. Kako kaže poslovica, „U radu je spas.” Tako se osobe s invaliditetom koje bi se zaposlile ne bi se loše osjećale i ne bi bile odbačene iz društva. Bile bi komunikativnije i osjećale bi se korisnijima. Stekle bi nove prijatelje i opet bi dale poticaj drugim zaposlenicima, a i šefovima, da se više trude u životu i da više cijene život. Upravo tu je prilika za razvijanje i vježbanje u moralnim zadacima gdje je ključno izbaciti ego i šefovanje te prihvatiti novi mentalni sklop - ne „ja”, nego „mi”. Vrednota temeljena na egu ne može pustiti hijerarhiju od vrha prema dolje. ${ }^{20} \mathrm{~A}$ upravo taj pristup marginalizira osobe s invalidnošću. Kroz bolji vrijednosni sustav udaljenost između osoba s invaliditetom i onih bez nje smanjuje se i postupno nestaje. A zato nam je potrebno znanje iz bioetike i življenje tog znanja u praksi.

\subsection{Utjecaj invalidnosti na položaj u društvu}

Tijekom povijesti mijenjao se odnos društva prema osobama s invaliditetom. U prvobitnoj su zajednici prema njima bili netolerantni. Osobe s invaliditetom smatralo se nekorisnima, jer nisu bile u stanju sudjelovati u aktivnostima važnima za preživljavanje. Zbog toga su u kriznim situacijama (borba s drugim plemenima ili divljim životinjama, prirodnim nepogodama kao što su zima, glad, poplave itd.) bile prepuštene sami sebi. Bile su nezaštićene, kao teret koga se trebalo riješiti. Vrijednost pojedinca cijenila se, dakle, prema njegovu doprinosu u pribavljanju hrane i obrani. Čovjek je ono što u sebi gleda i za što se odlučuje. Kada ga nešto boli ili je depresivan, intenzivno razmišlja o bolesti i sažalijeva se. A potrebno je samo stvoriti odluku: ma pro- 
ći će to, odlučujem se za zdravlje, moj je duh jači... Stvaralaštvo je duhovna aktivnost koja se očituje u slobodi za stvaranje novih vrijednosti i boljeg života. Svjesno i iskreno djelovanje u slobodi trebalo bi biti uvijek i moralno djelovanje. Početi gledati sebe sposobnog i zdravog stvaralački je proces za koji je potrebna duhovna podrška. Ozdravljenje ne znači blagostanje i izlječenje, već sposobnost nositi se $s$ raznim životnim poteškoćama koje su prisutne kod svakog čovjeka bez obzira na njegovu invalidnost. Tada će se postupno događati promjena iz bolesti u zdravlje, iz patnje u prihvaćanje i radost. Potrebno je koncentrirati se na svoje sposobnosti, na ono dobro i zdravo u sebi... To je put smanjivanja jaza između materijalnog i duhovnog, što je danas teško s obzirom na poremećeni sustav vrijednosti u društvu. Ako je čovjek i sasvim hendikepiran, potrebno ga je poticati da živi ponosno i ostvaruje se u svojoj originalnosti, jer baš svaka osoba ima neku svoju posebnost, samo je ta osoba mora otkriti, a kada je otkrije, mora je razvijati i samo ići naprijed rušeći barijere i graditi mostove za bolji život. Duh je prkosan i ne da se pobijediti. Mnogo je jači od tijela. ${ }^{17}$ Ako je neka osoba bez jedne ruke, ima drugu kojom može stvarati; ako nema obje ruke, ima noge; njima može pisati i crtati... U tom je stavu čovjekova veličina. Čovjek nije na ovom svijetu da tuguje, nego da se bori. Volja, trud, želja, vjera u sebe i pozitivan stav vrlo su važni za uspješnost. Upornost i volja, ali i skromnost i poniznost kao vrline daju cilj. Postoje brojni primjeri poznatih osoba s invaliditetom koje su bile uspješne u životu. Jedan je od najuspješnijih svjetskih slikara Nizozemac Vincent Van Gogh koji je bolovao od psihičke bolesti, točnije depresije. Neupitno je da su njegove slike neizmjerno obogatile temelje moderne umjetnosti. U svojoj desetogodišnjoj karijeri naslikao je 900 slika i 1100 crteža. Postoje razne pretpostavke da je Ludvig Van Betoven imao problema sa sluhom koje prvi put spominje u pismu prijatelju kada je imao oko trideset godina. Ipak, njegova strast prema glazbi bila je toliko velika da je, čak i nakon što je potpuno izgubio sluh, neko vrijeme nastavio dirigirati, komponirati i svirati. Svaki put kada bi se na koncertu morao okrenuti prema publici da bi vidio aplauz bio je preplavljen emocijama, tako da se ipak u četrdesetim godinama povukao sa scene, ali je nastavio komponirati do kraja života. Za sobom je ostavio maestralna djela koja su i danas izazov glazbenicima širom svijeta, a njegovi zapisi s pomoću kojih je vodio konverzaciju predstavljaju neprocjenjiv izvor informacija o njegovu životu. Stephen William Hawking u mladosti je obolio od amiotrofične lateralne skleroze (ALS), paralizirajuće bolesti koja uzrokuje slabljenje tjelesnih mišića. ${ }^{20}$ Potpuno nepokretan, u kolicima, s vremenom je izgubio i sposobnost govora. S okolinom je komunicirao jedino uz pomoć računalnog sintetizatora glasa. Bolest nije oštetila njegov mozak, tako da se uspješno nastavio posvećivati svojem teoretskom radu. Završio je studij fizike na Sveučilištu Oxford. Doktorsku disertaciju iz kozmologije obranio je na Sveučilištu Cambridge. Već 1974. postao je članom Kraljevskog društva iz Londona, jednog od najstarijih znanstvenih udruženja na svijetu. Bio je profesor matematike i fizike na Lucasovoj katedri Sveučilišta Cambridge, istoj onoj katedri na kojoj su nekoć predavali velikani poput Isaaca Newtona i Paula Diraca. Ovi navedeni primjeri dokaz su da se sve može kada se želi i unatoč nekom invaliditetu i poteškoćama. Uopće nije upitno utječe li invalidnost na život. Svatko bi trebao dobiti šansu da pokaže svoju sposobnost. Pitanje morala stavljeno je pred svakog pojedinca, čime se god bavio. Prema filozofu Andreu Comte-Sponvilleu, poziv i zadatak raznovrsnih poduzeća i poduzetnika nisu da pokazuju naklonost, pažnju, brigu, empatiju ili bilo koji drugi osjećaj, nego je njihov cilj ostvariti uspjeh u poslovanju bez obzira na sve ostale čimbenike. ${ }^{20}$ To je izrečeno u duhu izričitog konzumerizma i kapitalizma te se postavlja pitanje je li moralno biti baš u tolikoj mjeri orijentiran na profit. Nažalost, u društvu u kojem se nalazimo i kapitalističkom dobu kojem pripadamo sve se manje pažnje obraća na ljude, a sve veća je pohota za novcem koji danas predstavlja temelj moći. lako su radnici donekle zaštićeni zakonima od strane države, u privatnim poduzećima često se ne poštuju zakoni s obzirom na plaće, broj radnih sati, slobodne dane i tako dalje. I „normalnim” se ljudima danas veoma teško zaposliti, a kada se i zaposle, susreću se s brojnim nepravilnostima i neugodnostima u radnom okruženju. Sada u kontekst svega navedenog treba i osobe $\mathrm{s}$ invaliditetom prilagoditi situaciji. Njima je i ovako, s obzirom na ograničenja koja imaju, teško pronaći adekvatno zanimanje i adekvatno radno mjesto. Stoga se postavlja pitanje je li moralno da poslodavci budu orijentiraniji na profit nego na ljudski kadar koji im u stvari i stvara taj profit, iako to često ne vide, te da im se čitav koncept poslovanja svodi na rezanje troškova koje najčešće pogađa zaposlenike. Kada ovdje govorimo o osobama s invaliditetom, koje imaju ograničene mogućnosti, koje možda nisu brze i efektivne kao zdrave osobe, koje možda nisu u stanju potpuno samostalno odraditi određene zadatke i koje se svakako susreću s poteškoćama na radnom mjestu koliko im god bilo prilagođeno - je li moralno ne zaposliti takve osobe jer postoji mogućnost da imaju utjecaj na smanjenje produktivnosti pa samim time i na smanjenje profita poduzeća? U Republici Hrvatskoj zakonom je određeno da svaki poslodavac na svakih 20 zaposlenika mora zaposliti jednu osobu s invaliditetom. Tako se na državnoj razini pokušava omogućiti osobama s invaliditetom sigurnije zaposlenje i lakši dolazak do radnog mjesta. Pozitivno je što se tako otvaraju radna mjesta osobama s invaliditetom, ali zar smo zbilja 
takvo društvo da država na taj način mora prisiljavati poslodavce da pruže šansu nekome tko je imao manje sreće u pogledu zdravstvenog stanja? Sve u svemu, nije moralno biti orijentiran na profit i pritom zanemarivati ljudski kadar. U svemu u životu mora postojati neka ravnoteža, pa tako i u tome. ${ }^{20}$

\subsection{Nova percepcija načela supsidijarnosti osobe s invaliditetom}

Sociološka bioetika ${ }^{23}$ dijaloška je disciplina gdje su uključena stajališta mnogih stručnjaka u rješavanju ljudskih problema, ali iz perspektive cjelovitosti, tako da se gleda čovjek koji ima um i dušu. Princip supsidijarnosti u prvom je redu pravilo za utvrđivanje nadležnosti pri ostvarivanju zajedničkog dobra. Društvo ne smije uskratiti ništa što pojedinac može izvršiti sam ili što može obaviti manja zajednica. Ono što svaki pojedinac može izvršiti vlastitom snagom, to mu nitko ne bi trebao oduzeti. Društvo bi trebalo pružati potporu. Timski se rad uvijek pokaže boljim i učinkovitijim. Elementarno moraju postojati sloboda i otvorenost. Sloboda implicira da radnik s invaliditetom napravi onoliko koliko može sam, a otvorenost se ogleda u predavanju nekih vještina drugim kolegama u timu koji to nesebično prihvaćaju. Krnji medijski pristup osobama s invaliditetom, tj. zapravo koliko su zastupljene u medijima ne smanjuje predrasude, već ih stavlja u težak položaj. Svaka je osoba s invaliditetom zasebna i njezin je problem individualan. Prema Marku Mariniću, ${ }^{24}$ važna je socijalna konstrukcija identiteta osobe s invaliditetom. Ona ne samo da utječe na njihovu samopercepciju nego bitno određuje i njihov položaj u društvu - uključujući i ostvarivanje osnovnih ljudskih prava. Tu veliku ulogu imaju upravo mediji, tj. vrlo je poznata činjenica da masovni mediji poput televizije, radija, internetskih portala i tiskanih medija snažno utječu na razmišljanja i stavove javnosti o raznim pitanjima, uključujući i percepciju osoba s invaliditetom. Medijski izvještaji o osobama s invaliditetom, posebice u manje razvijenim zemljama, najčešće bi se mogli podijeliti na dvije vrste. S jedne je strane negativan kontekst: govori se ponajprije o konkretnim problemima pojedinačnih osoba s invaliditetom, izvještaji su puni emotivnoga naboja, a osobe se prikazuju vrlo ranjivima, nesposobnima za život i na neki način samo vrijednima sažaljenja. S druge se strane u pozitivnom kontekstu o osobama s invaliditetom govori u superlativima, izvještaji su puni sentimentalnosti, osobu s invaliditetom predstavlja se kao superheroja zbog postizanja nekih uobičajenih stvari, poput završetka fakulteta, zapošljavanja, uspješne karijere, osnivanja obitelji... M. Marinić naglašava da su i u jednom i u drugom kontekstu, dakle bilo da su predstavljeni kao žrtve bilo kao heroji, osobe s invaliditetom zapravo diskriminirane, medijski su prostor dobile upravo zbog činjenice invalidnosti, pa se tako i njihov identitet temelji na invalidnosti. Naravno da to ne znači da treba ignorirati činjenicu invalidnosti jer je doista ta činjenica dio njihova bića, no sve dok je u prvom planu invalidnost, a onda iza toga neka sekundarna priča, teško ćemo se pomaknuti s mjesta i dopustiti osobama s invaliditetom da budu percipirane kao ravnopravni članovi društva. U Hrvatskoj je oko $12 \%$ osoba s invaliditetom, što bi zapravo značilo da bi, statistički gledajući, svaka osma ili deveta osoba koju vidimo na televiziji trebala biti osoba s invaliditetom, no je li to baš tako i kada se osobe s invaliditetom pojavljuju u televizijskom programu? Zašto se invalidnost ne prihvati kao nešto što je činjenica za dio populacije i od čega ne treba bježati? Zašto se, recimo, i na Hrvatskoj televiziji ne može dogoditi jedna Lucille Werner, odnosno da osoba s invaliditetom vodi popularnu emisiju kao što je kviz koji spomenuta gospođa usprkos invalidnosti vodi u Nizozemskoj? Ona se ne libi prošetati po studiju usprkos evidentnoj činjenici da joj je jedna noga kraća od druge, no svojim primjerom daje do znanja da je njezina invalidnost sekundarnoga i zapravo zanemarivoga karaktera jer je potpuno kompetentna za taj posao i obavlja ga izvrsno. Invalidnost doista konkretnoj osobi radi teškoće u životu i vjerojatno bi svaka osoba s invaliditetom voljela da tu invalidnost nema, no osobe se mogu više ili manje uspješno prilagoditi svojem stanju. Upravo je percepcija i reakcija okoline na takvo stanje ono što će omogućiti osobama s invaliditetom veću ili manju razinu ravnopravnosti u društvu. Jedini je način da se to dogodi da princip supsidijarnosti zaživi u praksi. ${ }^{20}$ To zvuči idealistički dok se osobe s invaliditetom u Hrvatskoj još uvijek bore za ostvarivanje osnovnih ljudskih prava, no činjenica je da ravnopravnosti, ma koliko je svima bila puna usta, neće biti dok se stvari i u tom smislu ne poslože na pravi način. Svaka osoba jednako je vrijedna bez obzira na invalidnost. Bit je svih problema u krizi morala. Jedino je rješenje stvarni zaokret u vrednovanju - ne „ja”, nego „mi”. U tom smjeru vodi nas znanje iz bioetike, ali i njegova primjena prvenstveno po principu solidarnosti i supsidijarnosti. ${ }^{20}$ Tada možemo očekivati veću ravnopravnost, ali i autonomiju osobe s invaliditetom.

\section{Zaključak}

Temelji ovog rada zasnivaju se na proučavanju bioetike kroz povijest te načela supsidijarnosti koji su ključ- 
ni za otvaranje novih horizonata u poštivanju, ljubavi i suosjećanju prema osobama s invaliditetom. Bioetika je područje koje integrira profesionalno znanje i vrline. Uspjeh svake struke i ustanove leži u timskom, a ne u pojedinačnom radu. Moderno društvo pretrpano tehnološkim i znanstvenim dostignućima mijenja prioritete i vrijednosti. Paternalizam se polako gubi, a prevladava holistički pristup. Suosjećajnost i ljudska toplina stvaraju pozitivnu atmosferu u timskom radu. Povezanost članova tima utječe na uspješnost i zadovoljstvo unutar tima. Danas je važna stručnost u formiranju tima, a zapostavljene su ljudska i etička dimenzija. Gdje su u toj priči osobe s invaliditetom? Bioetika i osobe $s$ invaliditetom imaju zajedničku poveznicu: autonomiju svake pojedine osobe. Bioetika je alat koji može pomoći osobama s invaliditetom riješiti etičke probleme u praksi, ali uz uvjet da princip supsidijarnosti zaživi na osobnoj razini. Ovaj rad želi početi taj hod. Nova percepcija načela supsidijarnosti osobe s invaliditetom jest bogatstvo u rješavanju ljudskih problema, ali iz perspektive cjelovitosti, tako da se gleda čovjek koji ima um i dušu. Supsidijarnost je načelo po kojem se odluke donose i problemi rješavaju u obliku kategorija i na razinama na kojima nastaju. Svi poslovni problemi rješavaju se u okviru funkcijske, logičke, kronološke i lokacijske kategorije, što je prikazano u središnjem dijelu rada. Princip supsidijarnosti pravilo je za utvrđivanje nadležnosti pri ostvarivanju zajedničkog dobra. Ono što pojedinac može sam izvršiti svojom vlastitom snagom, to mu društvo ne smije oduzeti. Taj princip govori nam da članovi neke zajednice imaju pravo na pomoć u poslovima kojima ne mogu izvršiti, ali isto tako kao članovi moraju biti zaštićeni od premoći same zajednice. Ne smije doći do uskraćivanja prava osobama s invaliditetom. Osobe $s$ invaliditetom sposobne su za zapošljavanje, ali ih poslodavci ne zapošljavaju dovoljno. To utječe na kvalitetu života i samu percepciju osoba s invaliditetom. Obveza je javnosti da osobe s invaliditetom smatra ravnopravnim članovima društva. Osobe s invaliditetom mogu ravnopravno obavljati razne poslove ovisno o stručnosti i funkcionalnosti. Neke životne prepreke ne bi trebale predstavljati probleme pri obavljanju poslova. Bitno je prihvaćanje okoline te princip solidarnosti. Ovim radom želi se pokazati koliko je važno da okolina i tim u radnom ozračju razviju pozitivniji odnos prema osobama s invaliditetom i da ih smatraju ravnopravnim suputnicima. Ta vizija može se ostvariti ako na svim društvenim razinama i među svim ljudima ponaosob u praksi zaživi supsidijarnost kao vrijedan model bioetike, upravo zbog humanizacije, smanjivanja otuđivanja čovjeka od čovjeka i podizanja kvalitete života.

\section{Referencije}

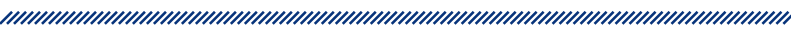

1. Čović A. Etika i bioetika. Razmišljanja na pragu bioetičke epohe, Zagreb: Pergamena; 2004, 91-122.

2. Kalauz S. Sestrinska profesija u svjetlu bioetičkog pluriperspektivizma, Zagreb: Pergamena; 2011, 228.

3. Čović A, Gosić N, Tomašević L (ur.). Od nove medicinske etike do integrativne bioetike, Zagreb: Pergamena; 2009, 20.

4. Jurić $\mathrm{H}$, Uporišta za integrativnu bioetiku u djelu Van Rensselaera Pottera, u: Valjan V (ur.). Integrativna bioetika i izazovi suvremene civilizacije, Sarajevo: Bioetičko društvo u BiH; 2007, 88-89.

5. Čović A. Filozofija i pluralizam, Izvorni članak UDK141.113., Zagreb: Sveučilište u Zagrebu, Filozofski fakultet.

6. Društvena istraživanja, god. 5; 1996, br. 3-4, 518-762.

7. Supek I. Znanost i etika, Zagreb: JAZU; 1985, 17.

8. Šegota I. Uz temu, Društvena istraživanja, god. 5; 1996, br. 3-4, 520

9. Filozofska istraživanja 71; travanj 1998, str. 733-950; Čović A (ur.). Izazovi bioetike, Zagreb: Pergamena - Hrvatsko filozofsko društvo; 2000.

10. Bioetika i znanost u novoj epohi, Filozofska istraživanja, 83; travanj 2001, 549-652; 84; siječanj 2002, 115-209; 85; veljača 2002, 507-555.

11. Čović A. O Lošinjskim danima bioetike. U: 6. Lošinjski dani bioetike, Zagreb: Hrvatsko filozofsko društvo; 2007, 13.

12. Mišić A. Rječnik filozofskih pojmova, Split: Verbum; 2000, 253-254.

13. Macan I. Socijalna etika i druge studije, Zagreb: FFDI; 2002, 37.

14. Zagorac I. Bioetički senzibilitet, Zagreb: Pergamena, Znanstveni centar izvrsnosti za integrativnu bioetiku; 2018, 11.

15. Biškup M. Ljudska prava, Zagreb: Kršćanska sadašnjost; 2010, 112.

16. Čehok I, Koprek I. Etika, Priručnik jedne discipline, Zagreb: Školska knjiga; 1996.

17. Reinders HS. The Future of the Disabled in Liberal Society: An Ethical Analysis. Notre Dame, IN: University of Notre Dame Press, 2000.

18. Brock B, Swinton J (ur.). Disability in the Christian Tradition: A Reader. Grand Rapids, MI: Eerdmans, 2012.

19. https://www.ncbi.nlm.gov./pubmed /21338030 (pristupljeno 9.2.2019.)

20. https://cbhd.org./content/bioethics-box-office-disability-ethics-edition(pristupljeno 9.2.2019.)

21. Bebek B, Kolumbić A, Poslovna etika, Zagreb; 2005, 110.

22. Muzur A, Rinčić I. Bioetička Europa našeg doba, struje, kormilari, sidrišta, Zagreb: Pergamena, Znanstveni centar izvrsnosti za integrativnu bioetiku; 2018, 56.

23. Šegota I. Bioetika i bioetička edukacija. U: Ivanišević g, Fatović-Ferenčić S (ur.). Bioetičke teme Hrvatskog liječničkog zbora, Zagreb: Medicinska naklada; 2012, 21.

24. Marinić M. Matematika ljudskog života (monografija), Zagreb: Institut društvenih znanosti Ivo Pilar; 2017. 


\title{
BIOETHICS AND AUTONOMY OF PERSONS WITH DISABILITIES ON THE PRINCIPLE OF SUBSIDIARITY
}

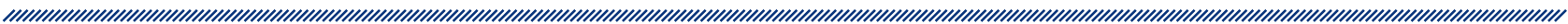

\author{
1 Mario Bebek \\ 1 Marija Brdarević \\ 1 University of Applied Health Sciences Zagreb
}

\section{Abstract

People with disabilities are capable of employment, but employers do not employ them enough. These facts have a significant influence on their quality of life as well as their self-perception. The principle of subsidiarity as part of applied bioethics can cause social changes and help address this problem. Demographic factors are devastating to the quality of life and work of people with disabilities. The negative effects of the moral crisis in the society point to the disagreement between the material and spiritual, moral and prevailing value system of society and affect the most vulnerable groups, namely persons with disabilities, in their education, work and personal life. Joint synergy between bioethics and practice is a journey towards the autonomy of people with disabilities. The public has to help and allow people with disabilities to be perceived as equal members of society. A positive outcome cannot be achieved without applying the principle of subsidiarity.

Keywords: bioethics, competence of persons with disabilities, subsidiarity principle, teamwork and multidisciplinary approach 